YAK 316.34/.35

ББК 60.54

DOI 10.22394/1682-2358-2017-5-101-107

N.I. Kuznetsov, Senior Lecturer of the Humanities and Social Sciences Department, Saratov Military Order of Zhukov Red Banner Institute of the National Guard of the Russian Federation

\section{SOCIAL ADAPTATION OF MILITARY STUDENTS \\ AS A SOCIOLOGICAL PHENOMENON}

Methodological approaches of social adaptation research are presented. The specificity of the manifestations of social adaptation of military students as a special group of the Russian society is revealed. It is proved that the formation of military students as soldiers is the result of not only educational socialization but also social adaptation that characterizes the adaptation of military cadets to the military and social environment, as well as the development of the existing civil-military relations, norms, behavior principles, values and traditions.

Key words and word-combinations: social adaptation, educational socialization, military students, the military.
Н.И. Кузнецов, стариий преподаватель кафедрьг гуманитарньгх и сочиальньгх наук Саратовского военного ордена Жукова Краснознаменного института войск национальной гвардии Российской Федераиии

(email: nikolai-kuznietsov-1978@mail.ru)

\section{СОЦИААЬНАЯ \\ АААПТАЦИЯ КУРСАНТОВ КАК СОЦИО ОГИЧЕСКОЕ ЯВ $\Lambda$ ЕНЕ}

Аннотаџия. Представлены методологические подходы исследования социальной адаптации. Изучена специфика проявления социальной адаптации курсантов как особенной социальной группы населения российского общества. Доказано, что становление курсантов как военнослужащих осуществляется в результате не только образовательной социализации, но и социальной адаптации, характеризующей приспособление курсантов к военно-социальной среде жизнедеятельности, а также освоение ими существующих военно-гражданских отношений, норм, принципов поведения, ценностей, традиций.

Ключевые слова и словосочетания: социальная адаптация, образовательная социализация, курсанты, военнослужащие.

B 2016 г. начамось формирование структур национамьной гвардии России. Согласно Фелерамьному закону «О войсках национальной гвардии Российской Федеращии» [1] одной из важнейших государственных задач сегодня является становцение эффективных военных организаций национамьной гвардии, обеспечение их способности сохранять законность и правопорядок на 
территории Российской Федерации. Аля решения этой задачи сформулированы новые стратегии, цели, определены механизмы формирования каАрового потенциала национальной гвардии. Обосновывается, что в современных усмовиях основной действующий субъект в военных организациях наџиональной гвардии - это офиџер. В связи с этим главной соџиальной задачей управления войсками национамьной гвардии явмяется формирование военно-профессионального потенџиала будущих офиџеров, соџиокумьтурное развитие, соџиальная и профессионально-трудовая аАаптация курсантов военных институтов как будущих офицеров военных организаџий России. В контексте разрешения данной социально-образовательной задачи на высшие учебные заведения возмагается государственная функџия - создание профессионально развитого офиџера как военного профессионала, соџиально-ответственной цичности, патриота.

Исходя из изложенного, становится очевидной актуальность исследования теоретического аспекта адаптации курсантов военных институтов как будущих офицеров, уточнения адаптаџионных проџессов их образовательно-профессионального развития и жизнедеятельности в целом.

Рассмотрим теоретические основы адаптации, уточним специфику проявления Аанной категории на уровне курсантов военных институтов. В научных источниках находим обоснование категории «адаптация». На абстрактном уровне адаптация рассматривается как проџесс целенаправленного приспособления субъекта к меняющимся внешним и внутренним условиям функџионирования организаџий разных форм и видов [2]. Соџиальная аАаптация - это проџесс, включающий в себя не только непосреАственное приспособление человека, но и формирование адаптивного потенциала, позвомяющего, во-первых, осознавать изменения в окружающей среде; во-вторых, осуществлять соџиальную деятельность без соџиальных конфликтов; в-третьих, стабильно поддерживать необходимую результативность деятельности; вчетвертых, в полной мере удовлетворять свои функциональные потребности; в-пятых, иметь возможность развивать и реализовывать функщионально-деятельные способности [3].

По сути, адаптаџия представцяет собой возможную соџиальную способность человека, реализующуюся в проџессе соџиализаџии и характеризующую возможность сохранять деятельную устойчивость в условиях трансформаџии среды его функционирования. Отметим, что мюбая соџиальная адаптаџия, с одной стороны, связана и осуществцяется одномоментно с проџессом соџиализаџии человека, с Аругой - зависит и определяется соџиальной средой, в которой реализуется его деятельность, проявляются соџиально-деятельные связи и отношения [4]. Она ориентирована на осуществление «практик приспособления, при которых деятельность цичности как субъекта аАаптаџии преАставмяет собой причину и слеАствие по отношению ответных мер и действий представителей внешних соџиальных групп семьи» [5, с. 87].

Исследуем данные теоретические подходы применительно к жизнедеятельности курсантов военного института, преАставцяющих собой спеџи- 
фический субъект соџиальных отношений. Их жизнедеятельность проходит в условиях жестких норм и правиц военного института, который обеспечивает полный материальный достаток, оптимальное удовцетворение потребностей в питании, жилье, одежде и в то же время активизирует механизмы тотального соџиального контроця, всецело и бескомпромиссно регламентирует все формы служебной и бытовой деятельности, определяет динамику развития профессионального и профессионально-адаптивного потенщиала акторов.

ААаптация курсантов - это процесс их цеменаправленного приспособмения к внешним и внутренним условиям функщионирования военной организации. Она преимущественно характеризуется подчиненными, конформными практиками освоения организационной культуры военного института, формированием и реализаџией адаптивного потенџиала курсанта. Реализаџия его внутренней, а также внешней адаптации опредемяется не только трансформацией трудовой деятельности, но и практиками формирования физического и мотивационного потенџиалов [6, с. 95-101]. ААаптация курсантов включает в себя следующие процессы: формулирование и конкретизацию задач, направленных на формирование внешнего и внутреннего механизмов приспособления; реализаџию данных задач и анализ результативности их осуществления; непосреАственную проверку эффективности последовательных технологий осуществления решений, определяющих трудовую сферу; прогнозирование и уточнение результатов реализации задач адаптации [7, с. 103].

При этом сохраняются некоторые активные модели воздействия на бытовую и культурную внешнюю среду акторов. Ряд авторов убедительно доказали, что механизм адаптационного развития определяет цеменаправленную разработку и внеАрение проектов образовательного, а также научно-творческого адаптационного потенциала акторов деятельного взаимодействия [3]. Образовательную соџиализацию и адаптаџию курсантов необходимо рассматривать как единый, взаимосвязанный проџесс. ААаптаџия курсантов означает проџесс приспособления акторов к существованию в военном комлективе, формирование способностей подстраиваться к изменяюшимся условиям предметного взаимодействия, а также явмяется условием и результатом активной образовательной соџиализаџии, направменной на усвоение норм, ценностей, традиџий, потребностей, интересов военной организации.

На практике проявляется несколько типов адаптации курсантов. Наиболее существенные из них два: нормальная, представмяющая собой конструктивный процесс, и девиантная - деструктивные процессы, дезадаптационные практики. Нормальная соџиальная адаптация опредемяется адекватным поведением курсанта относительно формальных норм и правил военного института, соответствием процессов его социализации динамике изменений условий соџиальной среды функционирования. По сути, нормальная соџиальная адаптаџия курсанта позволяет ему успешно осознавать и осваивать меняющиеся 
требования среды жизнедеятельности. Последнее предусматривает не только Аинамичное приспособление к факторам внешней соџиальной среды, но и эффективное функџионирование, успешное осуществление трудового накопцения деятельного адаптивного потенциала без признаков роста соџиальной напряженности в комективе в цемом. Нормальная общественная адаптация приводит к устойчивому приспособлению кичности курсанта при различных трансформаџионных процессах среды функџионирования, наличии ее типовых флуктуаџий, формировании типичных соџиальных противоречий и групповых проблем взаимодействия. В данных условиях деструктивные проџессы в коммективах военного института не приводят к сушественным нарушениям эффективности практик функџионирования курсанта, при этом не возникает условий Амя негативных структурных сАвигов и деформаџий в соџиальной среде их взаимодействия.

Аевиантная адаптация характеризуется несоответствием проџессов социализации изменениям условий функциональной среды курсанта: негативными проявлениями в рамках обеспечения приспособления и удовцетворения потребностей курсантов мибо несоответствием ожиАаний администрации военного института ици иных участников общественных взаимодействий, отторжением комлективом некоторых поведенческих практик курсантов.

Аевиантная соџиальная адаптаџия имеет свои особенности проявления. Курсант находится в относительно замкнутой среде, поэтому и приспособмение представляет собой более сложный и разносторонний проџесс, преАусматривающий не только формирование спеџиального адаптационного потенциала военнослужащего, но и реализацию определенного уровня общественной активности курсанта, развитие опыта такого рода с внутренней и внешней средой военного института. Последнее как раз и призвано привести к формированию соџиально значимого, а значит необходимого и ожидаемого соотношения стратегий, цемей, задач, потребностей и интересов мичности курсанта, отдельных групп обучаемых, администраџии и трудового комлектива военного института в целом. Социальная адаптация курсанта не имеет девиантных проявлений только тогда, когда в военном институте обеспечиваются условия интеграции индивидуамьных и коммективных цемей и задач, социальных потребностей, реализаџии интересов курсантов на основе коммективной совместной деятельности акторов.

Условно можно выделить следующие этапы соџиальной адаптаџии курсантов.

Во-первых, начальный этап - предадаптационная подготовка. В периоА обучения в школе, на стадии поступления в военный институт актор делает сознательный военно-профессиональный выбор. Он преАполагает будущее освоение военной специальности, неформально планирует предстоящие трансформации в системе собственной жизнедеятельности. На этом этапе молодой человек активно и целенаправленно познает и исследует нормы военной организаџии, особенности военно-профессиональной деятельности офиџера, ценности военной службы. 
Во-вторых - этап первоначального социального напряжения. В первые Ани в военном институте актор проходит курс молодого бойџа, идет начальная фаза формальной образовательно-военной соџиализаџии, формируются соџиальные механизмы переадаптации бывших абитуриентов. При этом существенно накапливается неопределенность, возрастает напряжение, формируется неуверенность, неудовлетворенность физических и функциональных потребностей курсантов, падает деятельная активность курсантов. Объективно мобилизуются их внутренние ресурсы, зарожАаются основы их адаптационного потенциала.

В-третьих - дезадаптация (первичная или вторичная). В первые месяџы в военном институте у актора, как правило, появцяется не только неуверенность, но и некомфортность общественного взаимодействия, усиливается отмичие интересов и функщиональных потребностей, нарастает напряженность, обостряются конфциктные практики на горизонтальном и вертикальном уровнях общественного взаимодействия. Всякая деятельность явмяется нестабильной, неустойчивой и часто непредсказуемой, ведь старые соџиальные технологии, реакџии на изменяющиеся условия уже не действуют и не могут обеспечить необходимого устойчивого взаимодействия на горизонтальном и вертикальном уровнях военного института. На данном этапе повышается значение разАражителей внешней среды, формируются экстремальные условия, нестандартные факторы проявляются как фрустрирующие, непреодолимые преграды соџиальной деятельности. В итоге обостряются конфцикты межАу группами курсантов, межАу курсантами и представитемями администраџии. Рассогласовывается процесс удовлетворения традиционных функциональных потребностей, не воспринимаются конструктивно спеџифические нормы поведения, организационные ограничения, не усваиваются военно-организационные ценности дисџиплины и порядка. Первичная дезадаптация - самый сложный и непредсказуемый этап, когАа деятельность акторов может быть как конструктивной, так и разрушительной.

В рамках конструктивных практик курсант-новичок активирует собственную деятельность, направленную на изучение изменяющейся обстановки, находит положительные и отрицательные моменты в сложившейся ситуации, ищет варианты изменения собственных соџиальных практик, оптимизирует поведение и в итоге находит выход из непредсказуемых ситуаций, конфАиктных проявлений сослуживцев, ситуаций рассогласованности интересов. В рамках разрушительных практик у курсанта-новичка проявляется полное рассогласование собственных потребностей, а также жестких ограничений. Формируется непонимание путей и способов стабимьного удовлетворения функщиональных потребностей.

Разрушительные дезадаптационные практики приводят к двум формам негативных проблем: 1) соџиальной агрессии (искусственной атаке, а впоследствии и разрядке); 2) уходу от существуюшей реальности (преАставлению заявления об отчислении из военного института, бегству от противоречий). Условно соџиальную агрессию можно охарактеризовать 
как попытку активного отстранения (им^юзии цемевого уничтожения) возникшей проблемы. При этом на практике осушествцяется разрушение усмовий и возможностей успешного социацьного функционирования курсанта. ЗАесь могут проявцяться бессвязные попытки девиантного поведения, развязывания беспочвенного конфликта, чувственные вспышки (ярость, непонимание, гнев, недовольство, требования изменения внешних функциональных условий). Уход от существующей реальности представляет собой процесс полной девацьвации приспособленческого потенциала, потерю способности Аальнейшей эффективной аАаптации курсанта. В отдельных случаях возможны апатия, самобичевание, депрессивное проявцение поведения.

В-четвертых - устранение дезадаптационного напряжения, реакция «выхода» курсанта из дезадаптационного состояния. Результат формальной или неформацьной соџиализаџии - накопление адаптационного потенџиала, его Аеятельная реализация, направленная на привыкание к изменениям внешней социальной среды военного института, возвращение прежних реакций на изменения, формирование новых целесообразных реакций. В конечном итоге эффективная социализация направленна на саморазвитие необходимых способностей адаптироваться к постоянным изменениям.

Таким образом, становление курсантов как военных офицеров осуществляется в результате Авойственных проџессов: общественной аАаптации и образовательной социализации, что в конечном итоге ориентировано не только на приспособление акторов к военно-социальной среде жизнедеятельности, но и на освоение ими сушествующих военно-гражданских отношений, норм, принџипов поведения, ценностей, традиций, формирования оптимальной модели коммуникаџионного взаимодействия с представителями военно-социальной среды. ААаптация курсантов призвана обеспечить приспособле-

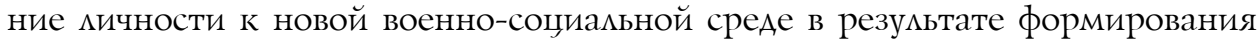
аАаптивного военно-профессионацьного потенциала и его реацизации, проявление умений оџенивать, обобщать и анализировать изменения ситуаџии общественного окружения, осознания мичных возможностей, трансформации поведенческих стратегий, целей и задач собственной деятельности в контексте изменяющейся обстановки. Предполагается также формирование и реализация адаптивных военно-профессиональных способностей органического приспособления к изменяющимся условиям внешней соџиальной среды, а также Аемонстрация устойчивого умения подАерживать свое поведение на необходимом уровне в соответствии со стратегическими цемями и задачами военной организации. В данном контексте адаптационный военнопрофессионацьный потенциал представцяет собой не только определенный набор военно-профессиональных знаний, умений, навыков, но и систему свойств кичности курсанта, уровень его культуры, вкАючающей ценности Аисциплины, органичного поведенческого приспособления, порядка, приверженности к административному послушанию, подчинению имеющимся административным требованиям, соџиальным ожиданиям руководства, пот-

106 Bulletin of the Volga Region Institute of Administration • 2017. Vol. 17. № 5 
ребности подчинения жестко установленным ролям в структуре властных отношений военной организации, иными словами, способность к реализации деятельных практик, направленных на приспособление как реакцию на изменение и воздействие внешней соџиальной среды жизнедеятельности в военном институте.

Реализация адаптаџионных потенџиальных способностей создает возможность нормальной жизнедеятельности курсантов в условиях сложной социально-функциональной среды военной организации, достижение необходимой эффективности взаимодействия с военно-трудовым колмективом. ААаптационные способности курсанта опредемяют его возможность согласо-

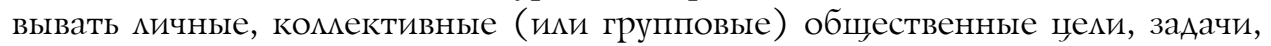
потребности, а также координировать, опредемять трансформацию мичных и коммективных деятельных практик. В связи с этим неадаптивность проявцяется как рост соџиальных противоречий курсанта, профессиональных групп военного института в целом. Она определяет несоответствие между цемями, задачами, потребностями социально-профессиональных групп, разбалансированность результатов деятельной активности курсанта и соџиальных ожиАаний администрации военного института, военно-профессионального колмектива. Аанную разбалансированность можно рассматривать на нескольких уровнях идентификаџии: 1) согласованности цемей; 2) интеграџии решения трудовых заАач; 3) удовлетворения социальных и трудовых потребностей; 4) ориентаџии и реализаџии интересов. Внешне противоречия несовпадения интересов проявляются в неэффективности образовательно-деятельных практик курсантов, рассогласовании целей и намерений, конфмиктов индивида с администрацией института, трудовым коммективом или обществом в цемом.

\section{Библиографический список}

1. О войсках национальной гвардии Российской Федерации: Федер. закон от 3 июля 2016 г. № 226-Ф3 // Российская газета. Федеральный выпуск. 2016. № 7014 (146).

2. Андреева Д.А. О понятии адаптации: Исследования адаптации студентов к обучению в вузе // Человек и общество. 2006.

3. Баландина T.M., Немоляев В.В. Социальное конструирование профессиональной культуры работников организации // Вестник Саратовского государственного социально-экономического университета. 2015. № 5 (59). С. 197-200.

4. Быченко Ю.Г., Баландина Т.М. Современная социологическая интерпретация общественного воспроизводства // Известия Саратовского государственного университета. Новая серия. Сер.: Социология. Политология. Т. 15, вып. 3. 2015. № 3. С. 46-52.

5. Хвостанцев С.В. Социальная адаптация семьи в условиях современного этапа социальных реформ // Вестник Поволжского института управления. 2015. № 3 (48).

6. Немоляев В.В., Пихтелв А.М. Конструирование социально-профессионального развития офицеров национальной гвардии России // Вестник Поволжского института управления. 2017. T. 17, № 3 .

7. Хвостанцев С.B. Социальный контроль процессов трудовой адаптации семьи офицера // Профессионализм военнослужащего: стратегия и перспективы развития в современной России: сборник научных статей. Саратов, 2016. 